\title{
Behavioural strategy: Adaptability context
}

Katarzyna Piórkowska, Ph.D. Wroclaw University of Economics, Department of Strategy and Management Methods
Life is only possible by the presence of adaptability

O. Nagel (1908)

\section{Introduction}

The paper is embedded in the following fields: strategic management in terms of behavioural strategy concept, adaptability construct, and micro-foundations realm as well as organizational theory and psychology. Moreover, the paper concerns to some extent a multi-level approach in strategic management involving individual, team, and organizational level.

Behavioural strategy concept pertains to different levels of analysis and its intention is to explain how particular forms of CEO or top management teams' behaviour arise in and amongst organizations as well as how and through which mechanisms it affects organizational strategies. The understanding of the behavioural strategy adopted for the paper's purpose is as follows: 'Behavioral strategy merges cognitive and social psychology with strategic management theory and practice. Behavioral strategy aims to bring realistic assumptions about human cognition, emotions, and social behavior to the strategic management of organizations and, thereby, to enrich strategy theory, empirical research, and real-world practice' (Powell, Lovallo, Fox 2011, 
p. 1371). Consequently, the phenomenon 'behavioural strategy' is involved in the micro-foundations realm in strategic management ${ }^{1}$ that in general constitutes theoretical explanation of phenomena at higher epistemological levels using constructs of lower epistemological levels.

Not only is the behavioural strategy concept considered at different levels of analysis, yet adaptability is also specified from the individual level via team level to the organizational one. While the research on individual, team, and organizational adaptability has been extensively conducted by scholars, the attempts to combine organizational adaptability with individual one have not been frequent. Additionally, adaptive performance as the unidimensional construct related to adaptability reflects behaviour occurring at the task, team, and organizational level (Griffin, Neal, Parker 2007; Griffin, Parker, Mason 2010), however, the main scholars' focus is on the task-level adaptive performance (e.g. Le Pine 2005; Griffin, Parker, Manson 2010; LePine, Colquitt, Erez 2000).

Hence, the aim of the paper is to fill that gap and contribute to extend, on one hand, the ascertainment set in the field of behavioural strategy since behavioural strategy encompasses a mindboggling diversity of topics and methods and its conceptual unity has been hard to achieve (Powell, Lovallo, Fox 2011, p. 1371), and on the other hand, to order mixed approaches to adaptability, especially to gain insights on micro-level adapting processes (individual adaptability and adaptive performance) in terms of the multi-level approach. The aim has been realized through developing an extended research framework at three level of analysis.

The method that has been used is literature studies and the interference is mostly deductive.

The structure of the manuscript is four-fold. The first part involves the considerations in the field of adaptability and adaptive performance at the individual level. The issues of adaptability and adaptive performance at the team level have been presented in the second part. The third part encompasses the organizational adaptability assertions. Finally, the conclusion, limitations of the considerations highlighted as well as the future research directions have been emphasized.

The publication is realized in the scope of the project that has been financed by the National Scientific Centre in Poland on the basis of the decision no. DEC2012/05/D/HS4/01317.

1 The linkages of the behavioural strategy concept with micro-foundations in strategic management have been described in e.g.: (Piórkowska 2014, pp. 356-361; Piórkowska 2015, in press). 


\section{Adaptability and adaptive performance - individual level}

Organizations can be characterized as complex systems composed of adaptive and intelligent agents (Carley, Svoboda 1996, p. 138). Individual adaptability is involved into considerations concerning organizational change, workplace change, perceived organizational support, job satisfaction, uncertainty, or even conversation of resources theory (contextual and personal change resources such as meaning-making) (e.g. Van den Heuvel, Demerouti, Bakker, Schaufeli 2013). Researchers have begun to focus not only on overcoming change resistance, yet on enhancing adaptive attitudes such as openness, readiness to change, or willingness (Oreg, Vakola, Armenakis 2011). Since change creates uncertainty (change-related uncertainty) (e.g. Rafferty, Griffin 2006) that is a frequently experienced state during organizational change (e.g. Bordia Hobman, Jones, Gallois, Callan 2004), predispositions of change recipients including their adaptability and perceptions of environment, including internal environment conditions like organizational support, are becoming critical (Cullen, Edwards, Casper, Gue 2014, pp. 270-271; Lau, Woodman 1995).

The recent proliferation of interest in individual adaptability had emerged as the discernible effect of Ployhard and Bliese's studies (2006). They proposed an I-ADAPT model involving individual differences (trait-like individual differences) in adaptability defining as "an individual ability, skill, disposition, willingness, and/or motivation, to change or fit different task, social, and environmental features" and called KSAOs (Ployhard, Bliese 2006, p. 13). It constitutes the support provided for distinct lower-order factors contributing to overall individual adaptability. The authors differentiated the following eight dimensions of individual adaptability being determined by aforementioned KSAOs: crisis (being able to react to emergency situations), work stress (being able to remain diligent and constructive facing with work challenges), creativity (being able to provide innovative solutions), uncertainty (being able to effectively act under unpredictable conditions), learning (being able to acquire new skills and seek the ways to improve), interpersonal (being able to implement interpersonal skills), cultural (being able to learn various aspects of groups, organizations, cultures), and physical (being able to adjust to difficult and arduous tasks, even under difficult work conditions). Other selected definitions of individual adaptability used in various studies are presented in table 1.

As for R. E. Ployhard and P. D. Bliese (2006), the relationship between individual adaptability and performance is moderated by environmental adaptability requirements (stable and dynamic) which corresponds to D. C. Funder's (2006) 
framework illustrating interactive relationships between individual personality traits, behaviour, and environment.

Individual adaptability is a relatively stable individual difference influencing how individuals interpret and respond to a situation. Adaptable individuals tend to be more sensitive to environmental cues which means that more adaptable individuals reveal higher level of attention and individual mindfulness ${ }^{2}$. Moreover, adaptable individuals may be less vulnerable to resource loss and more capable of gaining resources - it refers to change resources like change information and psychological resourcefulness (e.g. meaning-making) (Van den Heuvel, Demerouti, Bakker, Schaufeli 2013, p. 13; Van den Heuvel, Demerouti, Schreurs, Bakker, Schaufeli 2009).

It has been evidenced that individual adaptability might predict adaptive change attitude (as e.g. willingness to change - Metselaar 1997), however, in conceptualizing individual adaptability, some researchers attract attention towards behavioural change (not only adaptability in terms of attitudes) and change-supportive adaptive behaviour (e.g. Shoss, Witt, Vera 2012; Griffin, Neal, Parker 2007) predicted by adaptability - individuals appear as complex adaptive agents. Van den Heuvel, Demerouti, Bakker, Schaufeli (2013, p. 12) stress that adaptive behaviour would benefit organizational adaptability as it refers to flexible behavioural responses and constitutes the component of employability. It is worth stressing the relationship between an individual adaptability construct and resilience models that include a) a compensatory model (personal characteristics lowering risk associated with changes), b) a challenge model (challenges strengthen individual ability to adapt), and c) a protective model (role of indirect factors lowering the risk associated with changes) (O'Leary 1998).

Table 1. Individual adaptability - selected additional definitions

\begin{tabular}{l|l}
\hline \multicolumn{1}{c|}{ Author } & \multicolumn{1}{c}{ Definition } \\
\hline $\begin{array}{l}\text { Van den Heuvel Demerouti, } \\
\text { Bakker, Schaufeli 2013, p. 12, } \\
\text { cf. Savickas, Porfeli 2012 }\end{array}$ & $\begin{array}{l}\text { The quality of being able to change, the ability to manage } \\
\text { transitions at work as well as being able to effectively manage } \\
\text { change-related stress. }\end{array}$ \\
\hline $\begin{array}{l}\text { Wang, Zhan, Mccune, Truxillo } \\
\text { 2011, p. 165 }\end{array}$ & $\begin{array}{l}\text { An individual's dispositional tendency to make active attempts } \\
\text { to adjust him or herself to fit new tasks and new environments. }\end{array}$ \\
\hline
\end{tabular}

2 The considerations in the realm of individual mindfulness, mindful organizing, and organizational mindfulness have been presented in: (Piórkowska 2015, in press). 


\begin{tabular}{l|l}
$\begin{array}{l}\text { Pulakos, Arad, Donovan, } \\
\text { Plamondon 2000, p. } 615\end{array}$ & $\begin{array}{l}\text { Individuals modify their behaviour to meet the demands of } \\
\text { a new situation. }\end{array}$ \\
\hline O'Connell, McNeely, Hall 2008 & $\begin{array}{l}\text { Handling ambiguity, dealing with uncertainty and stress, } \\
\text { and working outside traditional temporal and geographic } \\
\text { boundaries. }\end{array}$ \\
\hline Scott 1966 & $\begin{array}{l}\text { Broadly conceived, adaptation implies two kinds of matching: } \\
\text { a matching between the requirements of an organism and the } \\
\text { resources of its environment, and also a matching between } \\
\text { the requirements of an environment and the resources of its } \\
\text { inhabitants. Both organism and environment are presumably } \\
\text { subject to some degree of modification through action } \\
\text { of the other. }\end{array}$ \\
\hline Harvey 1966 & $\begin{array}{l}\text { The capacity to behave in ways maximally consonant with the } \\
\text { attainment of ends or goals. }\end{array}$ \\
\hline Chan 2000, p. 4 & $\begin{array}{l}\text { The process by which an individual achieves some degree of } \\
\text { fit between his or her behaviors and the new work demands } \\
\text { created by the novel and often ill-defined problems resulting from } \\
\text { changing and uncertain situations. }\end{array}$ \\
\hline & $\begin{array}{l}\text { Competencies that enable people to manage themselves in } \\
\text { relation to the demands of conformity and/or change in particular } \\
\text { situations. }\end{array}$ \\
\hline
\end{tabular}

Source: Van den Heuvel Demerouti, Bakker, Schaufeli 2013, p. 12; Savickas, Porfeli 2012; Wang, Zhan, Mccune, Truxillo 2011, p. 165; Pulakos, Arad, Donovan, Plamondon 2000, p. 615; O'Connell, McNeely, Hall 2008; Scott 1966; Harvey 1966; Chan 2000, p. 4;

Fine, Cronshaw 1999, p. 39

Cognitive abilities have been evidenced as a strong predictor of adaptability and adaptive performance as well (e.g. Bell, Kozlowski 2008; LePine 2005; LePine, Colquitt, Erez 2000; Allworth, Hesketh 1999). The most compelling cognitive predictors are recognized as attention (as well as mindfulness), consciousness (awareness), self-efficacy, and cognitive flexibility (including working memory capacity) - in general, they all pertain to transfer knowledge and problem solving in a new and altering context. Individuals differ in capabilities of accurately allocating (recognizing adaptation opportunities, altering behavioural changes, learning, and obtaining proper competencies) attentional resources to respond to contingencies in environment. Consciousness concerns processing attentional resources and individuals revealing high levels of consciousness are likely to be detail oriented, well organized, and successful in problem solving (Shoss, 
Witt, Vera 2012, p. 913; Barrick, Mount, Strauss 1993; Griffin, Hesketh 2005). Selfefficacy is thought, especially in the field of Bandura's Social Cognitive Theory, to constitute individual perception of how well an individual is able to perform a specific task (Bandura 1989). High self-efficacy results in enhanced efforts and persistence as well as in more challenging goals during skill acquisition (Vaughn III 2011, p. 21). Moreover, the learning dimension of individual adaptability is related to general self-efficacy (Vaughn, Tucker, Pleban 2011). Hence, self-efficacy is proposed to be considered as a mediator between individual adaptability and performance (including adaptive performance). These cognitive predictors aforementioned relate to cognitive flexibility - the capacity to flexibly interpret the context and respond to it (e.g. Martin, Rubin 1995; Herr 1993).

An adaptability construct is context-specific and at the individual level that context concerns mainly work environment characteristics (stable and dynamic) (O'Connell, McNeely, Hall 2008; Ployhard, Bliese 2006).

It ought to be noted that individual adaptability cannot be misunderstood and interpreted in terms of similar constructs like coping, adaptive performance, proactivity, proactive personality, psychological flexibility, cognitive psychology, openness to experience, etc. (e.g. Wang, Zhan, Mccune, Truxillo 2011; Parker, Collins 2010; Bateman, Crant 1993; Hirschfeld, Thomas, Bernerth 2011; Hamtiaux, Houssemand 2012).

Adaptability is frequently considered in terms of performance. Similarly, there is evidence supporting the relationships between individual adaptability and job performance - e.g. K. L. Cullen, B. D. Edwards, W. C. Casper, and K. R. Gue (2014) hypothesized and positively verified that perceived organizational support mediates the positive relationship between individual adaptability and job performance. Hence, as well as this, individual adaptability is associated with the construct called adaptive performance (how well individuals respond to task changes) that is a dynamic facet of performance in comparison with task performance, contextual performance, counterproductive work behaviour, and withdrawal behaviour that are considered as static views of performance (Shoss, Witt, Vera 2012, p. 911). That dynamism of adaptive performance involves the issues of acquiring competencies driven by learning processes. Despite criticizing for being specific to certain jobs and having been conducted as laboratory simulations, one of the most prominent studies on adaptive performance have been conducted by E. D. Pulakos et al. (2000, 2002). They proposed the following eight dimensions for examining adaptive performance: (1) handling emergencies and crisis situations, (2) handling stress in the workforce, (3) creative problem solving, (4) dealing with uncertain and unpredictable work 
situations, (5) learning and manipulating new technology, task, and procedures, (6) demonstrating interpersonal adaptability, (7) demonstrating cultural adaptability, (8) demonstrating physically oriented adaptability (Pulakos et al. 2000; 2002). The most critical difference between the dimensions of individual adaptability proposed by Ployhart and Bliese and those proposed by Pulakos et al. $(2000,2002)$ is that individual adaptability dimensions mainly refer to individuals traits while adaptive performance to behaviour, however, the adaptability was examined as a proximal (as for distal-proximal continuum) determinant of adaptive performance (Ployhart, Bliese 2006). Individuallevel adaptive performance contributes to organizational outcomes regarding a) managing change, b) organizational learning, and c) following changing customer expectation as well as is beneficial for task performance (Shoss, Witt, Vera 2012, p. 910). As well as individual adaptability construct does not mean the same what proactivity, adaptive performance does not constitute the same content what proactive performance phenomenon - adaptive performance refers to externally initiated changes, yet proactive performance reflects individuals' efforts to make changes (Shoss, Witt, Vera 2012).

Concluding, not only does macro (organizational) level play a significant role in executing organizational changes as the respond to changes in environment,

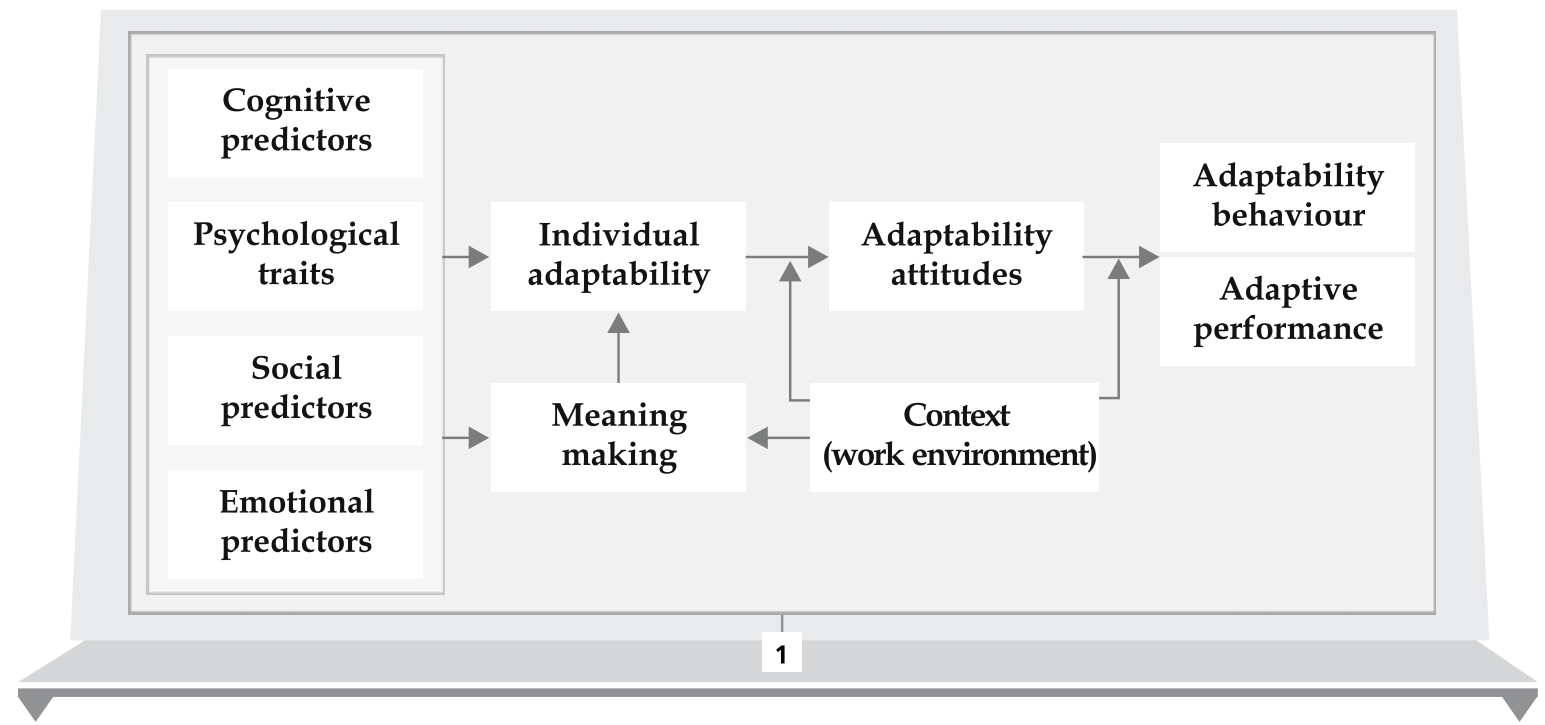

Figure 1. Individual adaptability in terms of attitude, behaviour (adaptive performance) as well as cognitive, psychological, and other (e.g. social, emotional) predictors

Source: own study 
yet individual ability to change is very salient since the individual constitutes the micro-foundation of the organization in terms of environmental and organizational change.

The logic of aforementioned thinking about individual adaptability in terms of attitude, behaviour (adaptive performance) as well as cognitive, psychological, and other (for instance: a) social: social awareness, social facility, prosocial behaviour, b) emotional: problem-focused and emotion-focused coping strategies - e.g. Zaccaro, Gilbert et al. 1991; Kohler, Munz, Grawitch 2006; Latack, Havlovic 1992) predictors has been presented in figure 1.

\section{Adaptability and adaptive performance - team level}

Individual adaptability influences team level adaptability as it refers indirectly to team member adaptability that in turn is determined by individual characteristics (traits like e.g. consciousness, self-leadership), cognitive abilities, and team composition. Additionally, team adaptability is likely to have impact on team adaptive performance where team goals, in terms of their difficulty and either performance or learning orientation, moderate the effects of the relationship between team adaptability and team adaptive performance (LePine 2005). Moreover, the relationship between team adaptability and team adaptive performance might be moderated by activities coordination (Burtscher, Wacker et al. 2010) in responding to environmental cues as well as team learning climate (Han, Williams 2008).

While individual adaptive performance concerns executing individual roles, team adaptive performance reveals the extent to which a team attains the goals during a transfer performance (Chen, Thomas, Wallace 2005). Consequently, the predictors of these constructs might be different. According to C. S. Burke, K. S. Stagl, E. Salas, L. Pierce, and D. Kendall (2006), team adaptive performance is regarded as a proximal temporal antecedent to team adaptation perceived as a change in team performance in response to cues leading to teams' outcomes. The process of team adaptive performance is involved in the four following interactive cross-level stages: (1) situation assessment, (2) plan formulation, (3) plan execution via adaptive interaction processes, (4) team learning. Emergent cognitive states like shared mental models, team situational awareness, or psychological safety constitute the outcomes and inputs to that cycle (Burke, Stagl et al. 2006). Those emergent states arising from member interaction and representing team cognition as well as an adaptive cycle comprise team adaptation. As well as this, it is argued that emergent cognitive states allow team 
members to engage in behavioural processes that result in effective adaptive performance (Zajac, Gregory et al. 2014). According to that team cognition and examining team adaptability, S. Zajac et al. (2014), suggest considering dimensions such as shared mental models (SMMs) (consisting of an organized knowledge structure or cognitive representation in terms of the following facets: task-based mental models, team-based mental models, equipment-based mental models, team-interaction-based mental models, and strategic mental models (Cannon-Bowers, Salas, Converse 1993; Cannon-Bowers, Salas 2001)) as well as transactive memory systems (TMSs) (regarding the dimensions: specialization, coordination, credibility due to learning, remembering, and communicating). The authors evidenced that shared mental models and transactive memory systems are paramount to gain high performance especially in terms of illdefined and unpredictable task environment (Zajac, Gregory et al. 2014, pp. 53-54). As well as this, they hypothesized that strategic mental models and transactive memory systems mediate the relationship between team learning and an adaptive team performance cycle (Zajac, Gregory et al. 2014, p. 65).

The proposal of research framework on team adaptability and team adaptive performance with regard to individual adaptability has been presented in figure 2 .

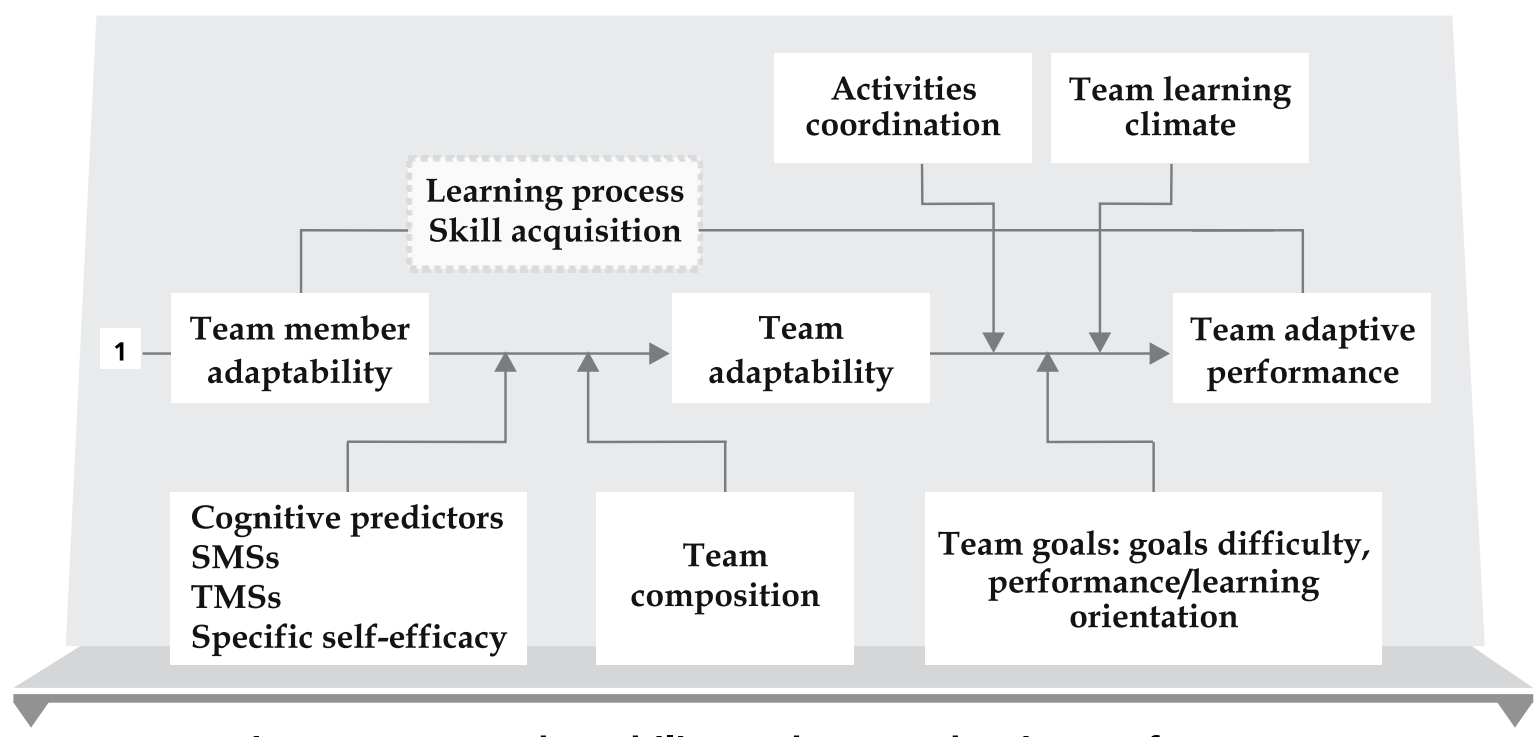

Figure 2. Team adaptability and team adaptive performance

Source: own study 


\section{Adaptability - organizational level}

Contemporarily, organizations face with dynamic and ever-changing environment. Strategic management theorists have argued that there is the necessity for organizational (strategy, culture, structure) fit with the external environment to achieve sustained firm-level performance (e.g. Barreto 2010; Venkatraman 1989), especially under the conditions of change. Organizational survival depends to a significant extent on the adjustment and renewal capacities of strategy-making processes (Burgelman 1991, p. 255). Hence, organizations must adapt or die (Wick 1995) and avoid structural inertia (Hannan, Freeman 1977). It means that so as to survive organizations have to adapt to environmental changes (e.g. Weick 1987), however, that fit can take different forms ranging from minor changes to radical ones (Lin, Hui 1997) as well as revealing in the following possible ways of fitting: relative inertia (a good fit of internal selection processes with the environment; reluctance to change organizational strategy), adjustment (relatively minor changes in strategy to accommodate environmental change), reorientation (major changes in strategy in response to major environmental change), and strategic renewal (major changes in organizational strategy for anticipatory adaptation to new environmental demands) (Burgelman 1991, p. 254). Organizational adaptation might be also posited from the lens of organizational learning as learning is one of the overarching processes in the response to changes. For instance, dynamic capabilities researchers regarded that competitive advantage depends on organization's idiosyncratic abilities to sense opportunities and threats in the environment and to respond to them via reconfiguring resources (Eisenhardt, Martin 2000; Teece, Pisano, Shuen 1997). Sensing is also associated with the attentionbased view advocating that organizations need to attend to the environment and its changes (Ocasio 1997; Ocasio, Joseph 2005). What is interesting, both individual and team adaptability, what was aforementioned, is predicted by cognitive factors including attention, mindfulness, consciousness, strategic mental models, specific self-efficacy, or transactive memory systems. Consequently, the attention-based view may be relevant in bridging macroand micro understanding of adaptive behaviour (adaptive performance) at the individual, team, and organizational level (see Shoss, Witt, Vera 2012, p. 911). According to W. Ocasio (1997, p. 189), an attention-based theory views firms as systems of structurally distributed attention in which the cognition and action of individuals are not predictable from the knowledge 
of individual characteristics but are derived from the specific organizational context. Moreover, he developed three premises underlying that perspective: a) at the individual level, the principle of focus of attention links attentional processing to individual cognition and behaviour, b) at the level of social cognition, the principle of situated attention highlights the importance of the situational context in explaining what decision-makers attend to, and c) at the organizational level, the principle of structural distribution of attention explains how the firm's structures regulate and channel issues that constitute the situational context of decision-making (Ocasio 1997, p. 189).

The success of adaptation to the environmental cues might be evaluated by organizational performance (Lin, Hui 1997) in terms of mainly non-financial measures like flexibility (e.g. Levy, Powell 2005, proposing the following its forms: preemptive flexibility: innovative use of technology, exploitive flexibility: using existing technology more competitively, protective flexibility: utilising technology to improve effectiveness, and corrective flexibility: learning from past mistakes).

The simplified proposal of examining organizational adaptability in terms of organizational performance has been illustrated in figure 3 .

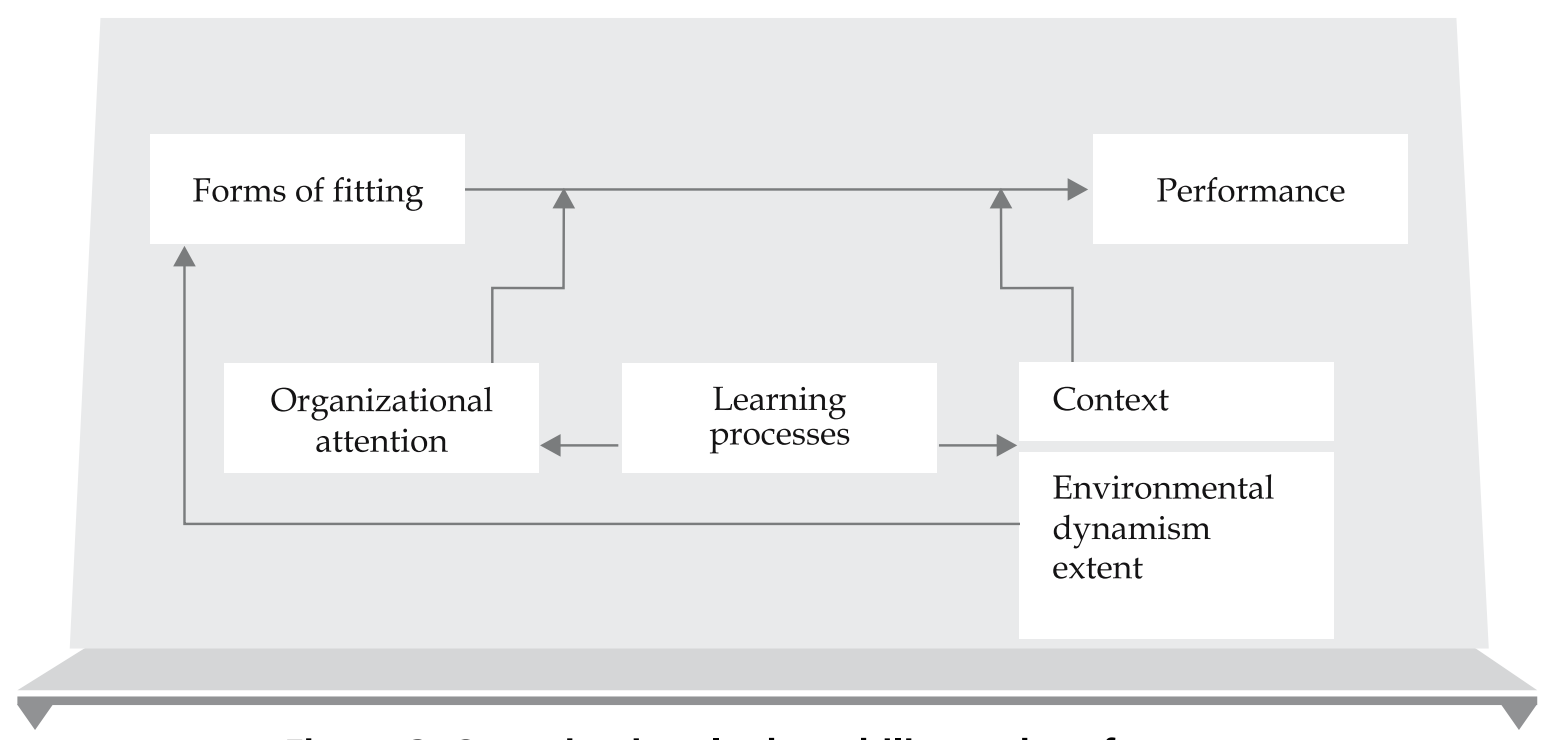

Figure 3. Organizational adaptability and performance

Source: own study 


\section{Conclusion}

In an effort to advocate the research on adaptability and performance using a multi-level approach as well as in corroboration with the points presented, the framework combining an individual adaptability with organizational one via team level, is proposed. In general, it has been shown in figure 4 and specifically in figure 1 , figure 2 , and figure 3.

Summarizing, the following research propositions and one conceptual ascertainment have been established:

Proposition 1: Individual adaptability is determined on one hand by individual characteristics like cognitive predictors, psychological traits, social, and emotional hallmarks, and on the other hand, by context (work environment) and meaning-making personal resources.

Proposition 2: Individual adaptability predicts adaptability attitudes (attitudes towards change) that in turn determine adaptive behaviour (adaptive performance) - the relationship between adaptability attitudes is moderated with the context, while adaptability attitudes may constitute the mediator in the relationship between individual adaptability and individual performance.

Proposition 3: Team member adaptability (individual adaptability) determines team adaptability and that relationship is moderated with cognitive predictors and team composition.

Proposition 4: Team adaptability influences team adaptive performance and that association might be moderated with activities coordination, team learning climate, and team goals (goals difficulty, performance/learning orientation).

Proposition 5. The relationships between team member adaptability and team adaptability, between team adaptability and team adaptive performance, as well as between team member adaptability and team adaptive performance are mediated with learning processes and skill acquisition.

Proposition 6: There are the relationships between particular forms of fitting and organizational performance as well as those relationships may be moderated with the context (environmental dynamism extent: the continuum from stable to dynamic) and organizational attention. In turn, learning processes might constitute the variable mediating relationships between organizational fit (in terms of adaptability) and organizational performance.

Ascertainment 1: The behavioural strategy concept may constitute the boundary spanner in exploring and explaining adaptability phenomenon at different levels of analysis. 


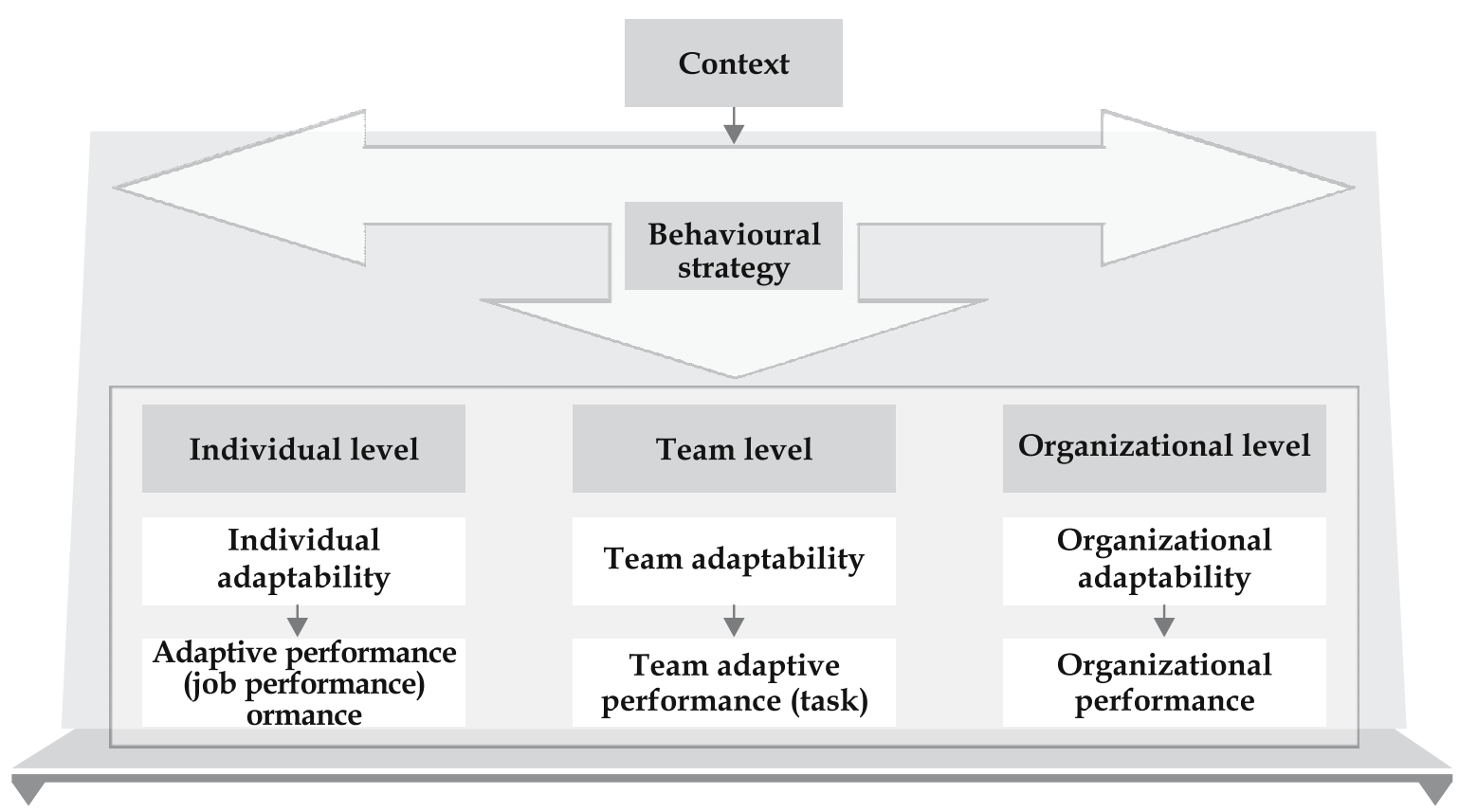

Figure 4. Behavioural strategy, context, and adaptability

Source: own study

Certainly, the considerations presented as well as ascertainment proposed are not by any means exhaustive and some limitations may be posited. First, stress coping styles in terms of relationships with adaptive performance have not been considered what simultaneously constitutes a research direction. Second, the issues concerning adaptive performance vs. task performance have not been taken into account as well. Third, values as antecedents of individual adaptability have not been explored what might be salient since for instance I-ADAPT theory highlights the aspects of adapting to particular context in terms of executing particular tasks irrespectively of a value system. Moreover, the article does not encompass the considerations of adaptability in terms of a systemic approach. Supposing, it would be more comprehensive to consider adaptability issues taking into account particular stages of changes (both environmental and organizational).

Even if the studies on adaptability, creativity, proactivity, and other similar constructs have been conducting for years (the first work e.g. Snow 1925, Thorndike 1903), they are still requiring the work on not only examining, yet also on conceptualizing (definitions and constituents still needs to be 
clarified). Hence, as for research directions, it is proposed to develop Ployhard and Bliese's model as it is difficult to be encompassed in a nomological network of other similar constructs. Specifically, Ployhard and Bliese's call (2006) for examining such mediators influencing the relationship between individual adaptability and performance like knowledge acquisition, strategy selection, self-regulation, and coping. It is worth and challengeable exploring the ways of measuring cognition at the individual, team, and organizational level. It seems to be interesting to explore the rigidity (inability to adjust) phenomenon as the opposite to adaptability since even if they constitute opposite constructs, they are both multi-dimensional so they seem not to remain exactly on one continuum (Steinmetz, Loarer, Houssemand 2011; Meresko, Rubin, Shontz, Morrow 1954). It is proposed to enhance social aspects of adaptability like social awareness, social facility, or prosocial behaviour as well as personality traits and facets, temperament, and emotional components as potential predictors of adaptability. It is also suggested developing research on adaptive performance and adaptability in general as most of the research either has been conducted in laboratory settings and has examined a student population or has used games and simulations.

Finally, research on adaptability ought to take into account dynamic aspects of performance, namely adaptive performance as well as its antecedents and consequences incorporating a multi-level approach. Nonetheless, such an approach leads to the relativity of adaptation so the frames of reference like the goal of the system with regard to which it is considered in terms of adaptation and the environment of the system ought to be specified.

\section{Summary}

\section{Behavioural strategy. Adaptability context}

The paper is embedded in the following fields: strategic management in terms of behavioural strategy concept, adaptability construct, and micro-foundations realm as well as organizational theory and psychology. Moreover, the paper concerns to some extent a multi-level approach in strategic management involving individual, team, and organizational level. The aim of the paper is to contribute to extend, on one hand, the ascertainment set in the field of behavioural strategy as behavioural strategy encompasses a mindboggling diversity of topics and methods and its conceptual unity has been hard to achieve (Powell, Lovallo, Fox 2011, p. 1371), and on the other hand, to order mixed approaches to adaptability, 
especially to gain insights on micro-level adapting processes (individual adaptability and adaptive performance) in terms of the multi-level approach. The method that has been used is literature studies and the interference is mostly deductive. The structure of the manuscript is four-fold. The first part involves the considerations in the field of adaptability and adaptive performance at the individual level. The issues of adaptability and adaptive performance at the team level have been presented in the second part. The third part encompasses the organizational adaptability assertions. Finally, the conclusion, limitations of the considerations highlighted as well as the future research directions have been emphasized. The overarching key finding is that the behavioural strategy concept may constitute the boundary spanner in exploring and explaining adaptability phenomenon at different levels of analysis.

Keywords: behavioural strategy, adaptability, adaptive performance, microfoundations.

\section{Streszczenie}

\section{Strategia behawioralna. Kontekst adaptacyjności}

Treść artykułu została zakorzeniona w następujących obszarach wiedzy: zarządzanie strategiczne (z perspektywy strategii behawioralnej, konstruktu adaptacyjności i mikro-fundamentów w zarządzaniu strategicznym), teoria organizacji oraz psychologia. W pewnym stopniu opracowanie plasuje się również w obszarze badań zjawisk na wielu poziomach analizy (poziom jednostki, zespołu i organizacji). Celem opracowania, z jednej strony, jest wzbogacenie wiedzy i ustaleń dotyczących zjawiska strategii behawioralnej, gdyż ze względu na różnorodność sposobów analizy wciąż nie wypracowano koncepcyjnego konsensusu (Powell, Lovallo, Fox 2011, p. 1371), a z drugiej strony, uporządkowanie rozproszonych podejść do konstruktu adaptacyjności zwłaszcza z perspektywy mikro (adaptycyjność jednostki) determinujacej pozostałe perspektywy rozważań (zespołu i organizacji). Zastosowano metodę ekstensywnego przeglądu literatury, a wnioskowanie ma charakter dedukcyjny. W pierwszej części opracowania omówiono adaptacyjność z punktu widzenia jednostki. Druga część odnosi się do 
rozważań nad adaptacyjnością na poziomie zespołu. W trzeciej części przedstawiono adaptacyjność z perspektywy organizacji. Ostatecznie, sformułowano wnioski końcowe, zidentyfikowano ograniczenia opracowania oraz zaproponowano dalsze kierunki badań. Kluczową konkluzję przedstawionych rozważań stanowi przypuszczenie, iż konstrukt "strategia behawioralna" zespala poziomy analizy dotyczące rozważań w obszarze adaptacyjności.

\section{Słowa}

kluczowe: strategia behawioralna, adaptacyjność, adaptacyjne wyniki, microfoundations.

\section{References}

1. Allworth E., Hesketh B. (1999), Construct-oriented biodata: Capturing changerelated and contextually relevant future performance, "International Journal of Selection and Assessment", Vol. 7, pp. 97-111.

2. Bandura A. (1989), Human agency in social cognitive theory, "American Psychologist", Vol. 44, pp. 1175-1184.

3. Barreto I. (2010), Dynamic capabilities: A review of past research and an agenda for the future, "Journal of Management", Vol. 36, pp. 256-280.

4. Barrick M., Mount M., Strauss J. (1993), Conscientiousness and performance of sales representatives: Test of the mediating effects of goal setting, "Journal of Applied Psychology", Vol. 78, pp. 715-722.

5. Bateman T.S., Crant J.M. (1993), The proactive component of organizational behaviour, "Journal of Organizational Behavior", Vol. 14 (2), pp. 103-118.

6. Bell B., Kozlowski S. (2008), Active learning: Effects of core training design elements on self-regulatory processes, learning, and adaptability, "Journal of Applied Psychology", Vol. 93 (2), pp. 296-316.

7. Bordia P., Hobman E., Jones E., Gallois C., Callan,V.J. (2004), Uncertainty during organizational change: Types, consequences, and management strategies, "Journal of Business and Psychology", Vol. 18, pp. 507-532.

8. Burgelman R.A. (1991), Intraorganizational Ecology of Strategy Making and Organizational Adaptation: Theory and Field Research, "Organizational Science", Vol. 2, No. 3, pp. 239-262.

9. Burke C.S., Stagl K.C., Salas E., Pierce L., Kendall D. (2006), Understanding team adaptation: a conceptual analysis and model, "The Journal of Applied Psychology", Vol. 91 (6), pp. 1189-207.

10. Burtscher M.J., Wacker J., Grote G., Manser T. (2010), Managing Nonroutine Events in Anesthesia: The Role of Adaptive Coordination. Human Factors, "The Journal of the Human Factors and Ergonomics Society", Vol. 52 (2), pp. 282-294. 
11. Cannon-Bowers J., Salas E., Converse S. (1993), Shared mental models in expert team decision making, [in:] N.J. Castellan, Jr. (ed.), Current issues in individual and group decision making (pp. 221-246), Lawrence Erlbaum Associates, Hillside, NJ.

12. Cannon-Bowers J.A., Salas E. (2001), Reflections on shared cognition, „Journal of Organizational Behavior", Vol. 22 (2), pp. 195-202.

13. Carley K.M., Svoboda D.M. (1996), Modeling Organizational Adaptation as a Simulated Annealing Process, "Sociological Methods \& Research”, Vol. 25, No. 1, pp. 138-168.

14. Chan D. (2000), Understanding adaptation to changes in the work environment: Integrating individual difference and learning perspectives, "Research in Personnel and Human Resources Management", Vol. 18, pp. 1-42.

15. Chen G., Thomas B., Wallace J.C. (2005), A multilevel examination of the relationships among training outcomes, mediating regulatory processes, and adaptive performance, "The Journal of Applied Psychology", Vol. 90 (5), pp. $827-41$

16. Cullen K.L., Edwards B.D., Casper W.C., Gue K.R. (2014), Employees' Adaptability and Percpetions of Change-Related Uncertainty: Implications for Perceived Organizational Support, Job Satisfaction, Performance, "Journal of Business and Psychology", Vol. 29, pp. 269-280.

17. Eisenhardt K.M., Martin J.A. (2000), Dynamic capabilities: What are they?, „Strategic Management Journal”, Vol. 21, pp. 1105-1121.

18. Fine S.A., Cronshaw S.F. (1999), Functional job analysis: A foundation for human resources management, Lawrence Erlbaum Associates Publishers, Mahwah, NJ.

19. Funder D. C. (2006), Towards a resolution of the personality triad: Persons, situations, and behaviors, "Journal of Research in Personality", Vol. 40, pp. 21-34

20. Griffin M.A., Neal A., Parker S.K. (2007), The new model of work role performance: Positive behavior in uncertain and interdependent contexts, "Academy of Management Journal", Vol. 50, pp. 327-347.

21. Griffin B., Hesketh B. (2005), Are Conscientious Workers Adaptable?, "Australian Journal of Management", Vol. 30(2), pp. 245-259.

22. Griffin M.A., Parker S.K., Mason C. (2010), Leader vision and the development of adaptive and proactive performance: A longitudinal study, "Journal of Applied Psychology", Vol. 95, pp. 174-182.

23. Hamtiaux A., Houssemand C. (2012), Adaptability, Cognitive Flexibility, Personal Need for Structure, and Rigidity, "Psychology Research”, Vol. 2, No. 10, pp. 563-585.

24. Han T.Y., Williams K.J. (2008), Multilevel Investigation of Adaptive Performance: Individual-and Team-Level Relationships, Group \& Organization Management", Vol. 33, pp. 657-684. 
25. Hannan M.T., Freeman J. (1977), The Population Ecology of Organizations, „American Journal of Sociology", Vol. 82, pp. 929-964.

26. Harvey O.J. (1966), Ends, means, and adaptability, [in:] O.J. Harvey (ed.), Experience, Structure \& Adaptability, Springer, New York, pp. 3-12.

27. Herr E.L. (1993), Contexts and influences on the need for personal flexibility for the 21st Century, "Canadian Journal of Counseling”, Vol. 27, pp. 148-164.

28. Hirschfeld R.R., Thomas C. H., Bernerth J.B. (2011), Consequences of autonomous and team-oriented forms of dispositional proactivity for demonstrating advancement potential, "Journal of Vocational Behavior", Vol. 78, pp. 237-247.

29. Kohler J.M., Munz D.C., Grawitch M.J. (2006), Test of a Dynamic Stress Model for Organisational Change: Do Males and Females Require Different Models?, „Applied Psychology: An International Review”, Vol. 55 (2), pp. 168-191.

30. Latack J.C., Havlovic S.J. (1992), Coping with job stress: A conceptual evaluation framework for coping measures, "Journal of Organizational Behavior", Vol. 13, pp. 479-508.

31. Lau C., Woodman R. C. (1995), Understanding organizational change: A schematic perspective, "Academy of Management Journal", Vol. 38, pp. 537-554.

32. LePine J.A., Colquitt J.A., Erez A. (2000), Adaptability to changing task contexts: effects of general cognitive ability, conscientiousness, and openness to experience, "Personnel Psychology", Vol. 53, pp. 563-593.

33. LePine J.A. (2003), Team adaptation and postchange performance: Effects of team composition in terms of member's cognitive ability and personality, "Journal of Applied Psychology", Vol. 88 (1), pp. 27-39.

34. LePine J.A. (2005), Adaptation of teams in response to unforeseen change: effects of goal difficulty and team composition in terms of cognitive ability and goal orientation, „The Journal of Applied Psychology”, Vol. 90 (6), pp. 1153-1167.

35. Levy M., Powell Ph. (2005), Strategies for growth in SMEs: The role of information and information systems, Elsevier Butterworth-Heinemann, Oxford.

36. Lin Z., Hui Ch. (1997), Adapting to the Changing Environment: A Theoretical Comparison of Decision Making Proficiency of Lean and Mass Organization Systems, "Computational \& Mathematical Organization Theory", Vol. 3 (2), pp. 113-142.

37. Martin M.M., Rubin R.B. (1995), A new measure of cognitive flexibility, „Psychological Reports”, Vol. 76, pp. 623-626.

38. Meresko R., Rubin M., Shontz F.C., Morrow W.R. (1954), Rigidity of attitudes regarding personal habits and its ideological correlates, "Journal of Abnormal and Social Psychology", Vol. 49, pp. 89-93. 
39. Metselaar E.E. (1997), Assessing the adaptive attitudes; construction and validation of the DINAMO, VU, Amsterdam.

40. Nagel O. (1908), The evolution of the senses, "Psychological Bulletin", Vol. 5 (2), pp. 349-350

41. Ocasio W. (1997), Towards an attention-based view of the firm, "Strategic Management Journal", Vol. 18, pp. 187-206.

42. Ocasio W., Joseph J. (2005), An attention-based theory of strategy formulation: Linking micro- and macroperspectives in strategy processes, "Advances in Strategic Management", Vol. 22, pp. 39-61.

43. O'Connell D.J., McNeely E., Hall D.T. (2008), Unpacking personal adaptability at work, „Journal of Leadership, Organizational Studies", Vol. 14, pp. 248259.

44. O'Leary V.E. (1998), Strength in the Face of Adversity: Individual and Social Thriving, "Journal of Social Issues", Vol. 54, No. 2, pp. 425-446.

45. Oreg S., Vakola M., Armenakis A. (2011), Change recipients' reactions to organizational change: A 60-year review of quantitative studies, "The Journal of Applied Behavioral Science", Vol. 47, pp. 461-524.

46. Parent J.D. (2006), Individual Adaptation to the Changing Workplace: Causes, Consequences and Outcomes, PhD dissertation, University of Massachusetts, Amherst.

47. Parker S.K., Collins C.G. (2010), Taking stock: Integrating and differentiating multiple proactive behaviors, "Journal of Management", Vol. 36 (3), pp. 632662

48. Piórkowska K. (2014), Behavioral strategies as micro-foundations in strategic management, "Global Business \& Economics Anthology", Vol. 2, December, pp. 356-361.

49. Piórkowska K. (2016), Behavioural strategy. The context of mindfulness, "Przegląd Organizacji", No. 4, pp. 60-67.

50. Ployhart R.E., Bliese P.D. (2006), Individual ADAPTability (IADAPT) theory: Conceptualizing the antecedents, consequences, and measurement of individual differences in adaptability, [in:] S. Burke, L. Pierce, E. Salas (eds.), Understanding adaptability: A prerequisite for effective performance within complex environments, Elsevier Science, St. Louis, MO, pp. 3-39.

51. Powell T.C., Lovallo D., Fox C.R. (2011), Behavioral strategy, "Strategic Management Journal", Vol. 32, pp. 1369-1386.

52. Pulakos E.D., Arad S., Donovan M.A., Plamondon K.E. (2000), Adaptability in the workplace: development of a taxonomy of adaptive performance, "Journal of Applied Psychology", Vol. 85 (4), pp. 612-624.

53. Pulakos E.D., Schmitt N., Dorsey D., Arad S., Borman W., Hedge J. (2002), Predicting Adaptive Performance: Further Tests of a Model of Adaptability, „Human Performance”, Vol. 15 (4), pp. 299-323. 
54. Rafferty A., Griffin M. (2006), Perceptions of organizational change: A stress and coping perspective, "Journal of Applied Psychology", Vol. 91, pp. 11541162.

55. Savickas M.L., Porfeli E.J. (2012), Career adapt-abilities scale: Construction, reliability, and measurement equivalence across 13 countries, "Journal of Vocational Behavior", Vol. 80, pp. 661-673.

56. Scott W.A. (1966), Flexibility, rigidity, and adaptation: Toward clarification of concepts, [in:] O.J. Harvey (ed.), Experience, Structure $\mathcal{E}$ Adaptability, Springer, pp. 369-400.

57. Shoss M.K., Witt L.A., Vera D. (2012), When does adaptive performance lead to higher task performance?, "Journal of Organizational Behavior", Vol. 33, pp. 910-924.

58. Snow A.J. (1925), Individual adaptability to occupation and profession, [in:] A.J. Snow (ed.), Psychology in business relations, A W Shaw Co., New York, pp. 465-484

59. Stachowski A.A., Kaplan S.A., Waller M.J. (2009), The benefits of flexible team interaction during crises, ,Journal of Applied Psychology", Vol. 94 (6), pp. 1536-1543.

60. Steinmetz J.P., Loarer E., Houssemand C. (2011), Rigidity of attitudes and behaviors: A study on the validity of the concept, "Individual Differences Research", Vol. 9, pp. 84-106.

61. Teece D.J., Pisano G., Shuen A. (1997), Dynamic capabilities and strategic management, "Strategic Management Journal”, Vol. 18, pp. 509-533.

62. Thorndike E.L. (1903), The influence of special forms of training upon more general abilities, [in:] E.L. Thorndike (ed.), Educational Psychology (pp. 8093), Lemcke \& Buechner, New York.

63. Van den Heuvel M., Demerouti E., Schreurs B.H.J., Bakker A.B., Schaufeli W.B. (2009), Does meaning-making help during organizational change? Development and validation of a new scale, "Career Development International", Vol. 14, pp. 508-533.

64. Van den Heuvel M., Demerouti E., Bakker A.B., Schaufeli W.B. (2013), Adapting to change: The value of change information and meaning-making, "Journal of Vocational Behavior", Vol. 83, pp. 11-21.

65. Vaughn III E.D. (2011), A Longitudinal Examination of Individual Adaptability as an Antecedent of Training and Transfer Outcomes, A PhD dissertation submitted to the Graduate Faculty of Auburn University, Auburn University, Auburn, Alabama.

66. Vaughn E.D., Tucker J.S., Pleban R.J. (2011), Individual adaptability incrementally predicts performance in a dynamic training environment, Poster presented at the 26th annual meeting of the Society for Industrial and Organizational Psychology, Chicago, IL 
67. Venkatraman N. (1989), The concept of fit in strategy research: Toward verbal and statistical correspondence, "Academy of Management Review”, Vol. 14, pp. 423-444.

68. Wang M., Zhan Y., Mccune E., Truxillo D. (2011), Understanding newcomers' adaptability and work-related outcomes: Testing the mediating roles of perceived P-E fit variables, "Personnel Psychology", Vol. 64, pp. 163-189.

69. Weick K.E. (1987), Organizational Culture and High Reliability, "California Management Review", Vol. 29 (2), pp. 112-127.

70. Wick C.W. (1995), From Ideas to Action: Creating a Learning Organization, "Human Resource Management", Vol. 34 (2), pp. 299-311.

71. Zaccaro S.J., Gilbert J.A., Thor K.K., Mumford M.D. (1991), Leadership and social intelligence: Linking social perceptiveness and behavioral flexibility to leader effectiveness, „Leadership Quarterly”, Vol. 2, pp. 317-342.

72. Zajac S., Gregory M.E., Bedwell W.L., Kramer W.S., Salas E. (2014), The cognitive underpinnings of adaptive team performance in ill-defined task situations: A closer look at team cognition, "Organizational Psychology Review", Vol. 4 (1), pp. 49-73. 